İş ve İnsan Dergisi | The Journal of Human and Work

Y1l | Year: Nisan | April 2018

Cilt-Sayı | Volume-Issue: 5 (1)

ss I pp: $19-32$

doi:10.18394/iid.361935

e-ISSN 2148-967X

http://dergipark.gov.tr/iid/

Araştırma Makalesi

\title{
Sağlık Çalışanlarında Sessizlik İle İlgili Yapılan Çalışmalara Yönelik Bir İnceleme
}

\author{
An Examination for Studies Related to Silence on Health Personnel
}

\author{
Birol Yetim ${ }^{\mathrm{a}}$, Gülsün Erigüç ${ }^{*, \mathrm{~b}}$
}

MAKALE BİLGISII

Anahtar Kelimeler:

Sessizlik, Örgütsel Sessizlik,

İşgören Sessizliği, Sağllk

Kurumları, Literatür

Incelemesi

Tarihler:

Geliş 05 Aralık 2017

Düzeltme geliș 31 Ocak

2018

Kabul 16 Şubat 2018

\section{A R TICLE INFO}

Keywords:

Silence, Organizational

Silence, Employee Silence,

Health Institutions,

Literature Review

Article history:

Received 05 December 2017

Received in revised form 31

January 2018

Accepted 16 February 2018

\section{ÖZ}

Bu çalışmanın amacl, örgütsel sessizlik ve işgören sessizliği ile ilgili Türkiye'de ve să̆llk alanında yapılmış olan araștırmaları incelemek; örgütsel sessizlik ve işgören sessizliği arasındaki ilișki ve farkları ortaya koyabilmek ve bundan sonra yapılacak olan çalışmalara yol gösterici olabilmektir. Örgütsel sessizlikve işgören sessizliği ile ilgili yapılmıs olan araştırmalara ulaşabilmek için YÖK Tez Arama Merkezi, Ulakbim, Google Akademik, Science Direct, Scopus ve EBSCOhost elektronik veri tabanları taranmıştır. Ulaşılan araştırmalar bu çalışma için belirlenen kriterlere göre elenmiş ve 27 araştırma çalıșmaya dâhil edilmiştir. Elde edilen tanımlayıcı bulgular, araştırmaların \% 85,1'inin örgütsel sessizlik ile, \% 14,8'inin ise işgören sessizliği ile ilgili olduğunu, örgütsel sessizlik çalışmalarının \% 43,4'ünün, işgören sessizliği çalışmalarının ise yarısının hemşireler üzerine yapıldı̆̆ını göstermektedir.

a İletişim kurulacak yazar, Arş. Gör., Hacettepe Üniversitesi, İktisadi İdari Bilimler Fakültesi, Sağlık Yönetimi Bölümü, Ankara, Türkiye. E-mail: birolyetim@ hacettepe.edu.tr.ORCID:0000-0002-1294-1874

*,b Doç. Dr. Gülsün Erigüç, Hacettepe Üniversitesi, İktisadi İdari Bilimler Fakültesi, Sağllk Yönetimi Bölümü, Ankara, Türkiye. E-mail. geriguc@hacettepe.edu.tr, ORCID: 0000-0001-5186-9345 


\section{GİRiş}

Özellikle son zamanlarda kendi kendine yeten, örgütsel demokrasinin hâkim olduğu örgütler oluşturulmaya çalışılmakta; çalışanların örgütsel süreçlere, örgüt ile ilgili eylem ve kararlara katılımının sağlanması amaçlanmaktadır. Ancak bazı nedenlerden dolayı örgüt çalışanlarının sessiz kaldığı, bilgi ve tecrübelerini sakladıkları görülmektedir. Bu durum ise örgütlerde yeniliğin ve yaratıcılığın önünde bir engel olmaktadır (Hasan \& Özcan, 2011: 108). Örgüt çalışanlarının davranışı örgütün geleceği ve faaliyetleri açısından da oldukça önemlidir. Dolayısıyla çalışan davranışlarının örgütsel gelişim üzerinde birtakım etkileri vardır (Bayın, Yeşilaydın \& Esatoğlu, 2015: 249). Çalışanların örgüt yararına olabilecek görüş ve düşüncelerini saklamaları olarak tanımlanabilen sessizlik, sağlık sektörü için ayrıca önemlidir. Çünkü sağlık kurumlarında sessizlik, sağlık alanında yaşanması muhtemel gelişimlerin sağlanamaması; hasta hayatı ile ilişkili bir takım risklerin de yanlışlıkla dile getirilememesi anlamına gelmektedir (Kılıçarslan, 2016: 2). Sağlık sektöründe çalışanların, sunulan hizmetin kalitesinde ve maliyetinde önemli rol oynadığı (Erigüç, 2012) düşünüldügünnde sağlık kurumlarında sessizlik çok daha önemli hale gelmektedir. Bu çalışmanın amacı, Türkiye'de ve sağlık sektöründe yapılmış olan araştırmaları incelemek, sağlık kurumlarında sessizlik kavramını, nedenlerini ve sonuçlarını ortaya koymak, yapılan çalışmalarda kullanılan ölçekleri tespit etmek ve yapılacak olan yeni çalışmalara yol göstermektir.

\section{IŞ̧GÖREN SESSIZZLIĞİ VE ÖRGÜTSEL SESSIZLLIK}

Sessizlik kavramını ilk defa kullanan Hirschman (1970) sessizliği, bir bağlllık göstergesi olarak ele almış ve sonraki çalışmalarda da sessizlik bağlılığın bir göstergesi olarak görülmeye devam edilmiştir (Çakıc1, 2007). Çalışan sessizliği önceleri uyum sağlama ya da bağlllık olarak düşünülse de günümüzde bu durum bir tepki ya da geri çekilme olarak algılanmaktadır (Bildik, 2009: 34). Yönetim yazını incelendiğinde; Morrison ve Milliken tarafindan 2000 yılında yapılan bir çalışmada, sessizlik kolektif bir olgu olarak ele alınmıştır. Bu çalışmalarında Morrison ve Milliken örgütsel sessizliğin nedenlerini, yöneticilerin olumsuz geri bildirim korkularına ve sıkı sıkıya bağlı oldukları inançlarına dayandırmakta ve örgütsel sessizlĭgi; işgörenlerin örgüt ile ilgili problemler hakkındaki fikir, düşünce ve kaygılarını bilinçli olarak gizlemeleri olarak tanımlamaktadırlar. Ayrıca sessizlik ilk kez bu çalışma ile birlikte bir bağlllık göstergesi olarak değil; örgütsel gelişim ve değişimin önünde tehlikeli bir engel olarak görülmüştür (Morrison \& Milliken, 2000: 707). Dolayısıyla sessizlik kavramının ilk zamanlarda işgörenin rahatsız olduğu durumlara karşı gösterdiği pasif bir tavır ya da bir kabullenme, bir bağll1ık göstergesi olarak ele alındığını ancak zaman içerisinde farklı şekillerde tanımlanmaya başladığını söylemek mümkündür (Tülübaş \& Celep, 2014: 281). Pinder ve Harlos tarafindan (2011: 334) sessizlik bireysel bir olgu olarak ele alınmış ve işgörenlerin verdikleri kararlar üzerine odaklanılmıştır. Yazarlar bu bağlamda işgören sessizliği kavramını kullanmışlar ve bu kavramı, değişiklik yapabilecek veya çözüm üretebilecek kişilerin örgüte ilişkin durumlarla ilgili davranışsal, bilişsel ve/veya duygusal değerlendirmeleri hakkındaki gerçek düşüncelerini ifade etmemeleri olarak tanımlamışlardır. Pinder ve Harlos sessizliğin beş özelliği ve bu beş özelliğin iki fonksiyonu olduğunu belirterek bu özellikleri şu şekilde ifade etmişlerdir (Pinder \& Harlos, 2011:338):

1. Sessizlik, insanları hem bir araya getirir hem de birbirinden uzaklaştırır.

2. Sessizlik, insan ilişkilerini hem zedeleyebilir hem de iyileştirebilir.

3. Sessizlik, hem bilgi sağlar hem de gizler.

4. Sessizlik, hem derin düşüncenin hem de düşünce yokluğunun işaretidir.

5. Sessizlik, hem kabulün hem de muhalefetin bir göstergesi olabilir.

Alan yazında, sıklıkla işgören sessizliği (employee silence) ve örgütsel sessizlik (organizational silence) kavramlarının karıştırıldığını ve birbirlerinin yerine kullanıldığını görmek mümkündür. Ancak bu iki kavram bazı noktalarda farklılıklar göstermektedir. Özellikle işgören sessizliğinin temelinde yatan unsurlar daha çok bireysel bazda yaşanan korku ve endişelerdir. Oysa örgütsel sessizlik genellikle örgüt yapısından kaynaklanan problemler nedeniyle meydana gelmektedir. Örgütsel sessizlik kolektif bir olgudur. Ayrıca işgören sessizliği zamanla tüm örgüt geneline yayılarak örgütsel sessizliğin oluşmasına neden olabilir (Morrison \& Milliken, 2000; Pinder \& Harlos, 2001: 334; Deniz, Noyan \& Ertosun, 2013: 693): 
Tablo 1: İ̧gören Sessizliği (Employee Silence) Ille Ilgili Yapılan Bazı Tanımlar

\begin{tabular}{cc}
\hline Yazar & Tanım \\
\hline Tangirala; \\
$\begin{array}{c}\text { Ramanujam } \\
\text { (2008) }\end{array}$ & "Kritik işler ile ilgili bilgilerin grup ïyelerinden kastli olarak gizlenmesidir."
\end{tabular}

Pinder; Harlos

(2011)

Eroğlu; Adıgüzel; Öztürk (2011)

Tülübaş; Celep

(2014)

\begin{abstract}
"Değişiklik yapabilecek veya çözüm üretebilecek kişilerin örgüt ile ilgili durumlarla ilgili davramı̧sal, bilişsel ve/veya duygusal değerlendirmeleri hakkındaki gerçek düşüncelerini ifade etmemeleridir. "
\end{abstract}

Tablo 2: Örgütsel Sessizlik (Organizational Silence) İle İlgili Yapılan Bazı Tanımlar

"işgörenlerin örgütsel gelişimin sağlanmast ve örgütsel sorunlarm çözümüne yönelik bilgi, düşünce, tavsiye ve önerilerini bilinçli olarak esirgemesi ve bunlan sözlü ya da yazıl olarak beyan etmekten kaçınmasıdır."

\begin{tabular}{|c|c|}
\hline Yazar & Tanmm \\
\hline $\begin{array}{c}\text { Morrison; } \\
\text { Milliken (2000) }\end{array}$ & $\begin{array}{c}\text { İgörenlerin örgütsel problemler hakkındaki fikir, düşünce ve kaygılarını bilinçli olarak } \\
\text { gizlemeleridir. }\end{array}$ \\
\hline $\begin{array}{c}\text { Henriksen; } \\
\text { Dayton } \\
\text { (2006) }\end{array}$ & $\begin{array}{l}\text { Örguitsel sessizlik, çalışanların örgüte tepki olarak, örgütün karşlaştığı önemli } \\
\text { problemlerin çözümünde çok az şey yapması ya da söylemesidir. }\end{array}$ \\
\hline $\begin{array}{l}\text { Çakacı } \\
(2007)\end{array}$ & $\begin{array}{l}\text { "isgörenlerin iyileşme ve gelişme adma işi veya isyyeriyle ilgili teknik ve'veya davranussal } \\
\text { komularla ilgili görüş ve düş̧üncelerini bilinçli olarak esirgemesi ve sessizleşmesi" }\end{array}$ \\
\hline
\end{tabular}

Tablo 1 ve Tablo 2'de sıklıkla kullanılan işgören sessizliği ve örgütsel sessizlik tanımları verilmiştir. Yapılan tanımlardan hareketle örgütsel sessizliği ile işgören sessizliği kavramlarının birbirinin yerine kullanıldı $\breve{1}$, tam olarak birbirinden ayrılamadı̆̆ 1 ve bir anlam karmaşıklığının olduğu söylenebilir. Bu nedenle çalışmanın bundan sonraki kısmında işgören sessizliği ve örgütsel sessizlik yerine genel olarak sessizlik kavramı kullanılacaktır.
Ancak gerektiğinde işgören sessizliği ve örgütsel sessizlik kavramlarına yer verilecektir.

\subsection{Sessizliğin Nedenleri}

Örgüt içinde çalışanların desteklenmemesi, astlar ve üstler arasındaki zayıf ilişkiler ve mevcut ilişkilerin samimi olmamas1, adaletsizlik algısı, olumsuz geri bildirim alma korkusu ve yöneticilerin bazı inançları; 
Tablo 3: Sessiz Kalmanin Nedenleri

\begin{tabular}{|c|c|}
\hline Örgütsel Nedenler & $\begin{array}{l}\text { - Adaletsizlik Külttüru } \\
\text { - Sessizlik İklimi } \\
\text { - Örgüt Kültirü }\end{array}$ \\
\hline Yönetsel Nedenler & $\begin{array}{l}\text { - Olumsuz Geri Bildirim Korkulan } \\
\text { - İ̧̧ ve İgörene Olan Önyargulı İnanı̧̧lar } \\
\text { - Yöneticinin Yapısı } \\
\text { - Yönetim Ekibinin Homojenliği }\end{array}$ \\
\hline Bireysel Nedenler & $\begin{array}{l}\text { - Güven Eksikliği } \\
\text { - Konuşmann Riskli Bulunması } \\
\text { - İolasyon Korkusu } \\
\text { - Geçmiş Tecrubeler } \\
\text { - Illişkileri Zedeleme Korkusu } \\
\text { - Karakter Özellikleri } \\
\end{array}$ \\
\hline Kültürel Nedenler & $\begin{array}{l}\text { - Külttïrel Yapı Ve Normlar } \\
\text { - Güç Mesafesi }\end{array}$ \\
\hline
\end{tabular}

işgörenlerin sessiz kalmasına neden olmaktadır (Batmunkh, 2011: 64). Öte yandan işgören sessizliği öznel ve soyut bir derinlik içerdiği için sessizliğin nedenlerini birtakım kalıplar içerisinde sunmak hatalı olacaktır. Ancak yapılan çalışmalardan hareketle işgören sessizlik nedenleri Tablo 3'deki gibi sınıflandırılabilir (Eroğlu, Adıgüzel, \& Öztürk, 2011: 102-103).

Sessiz kalmanın nedeni ne olursa olsun, bu durum hem örgüt hem de örgüt çalışanları açısından olumsuz sonuçlar doğurabilmektedir. Dolayısıyla sessizlik örgütler için yönetilmesi gereken bir süreç haline gelmektedir (Yeşilaydın \& Bayın, 2012: 4).

\subsection{Sessizlik Sınıflandırmaları}

Örgütlerde sessizlik kavramı tam olarak ortaya konulamamış olsa da farklı yazarlar tarafından farklı zamanlarda sınıflandırıldığı görülmektedir. Pinder ve Harlos (2011) sessizliği, işgören sükûneti ve kabullenici sessizlik olmak üzere ikiye ayırırken, Dyne, Ang ve Botero (2003) ise; kabullenici sessizlik, savunma amaçlı sessizlik ve örgüt yararına sessizlik olmak üzere üçe ayırarak sınıflandırmıştır. Öte yandan Kish-Gephart, Detert, Treviño ve Edmondson ise 2009 yılında yaptıkları bir çalışmada sessizliği; bilinçli olmayan savunmacı sessizlik, plan odaklı savunmacı sessizlik, bilinçli savunmacı sessizlik ve alışılmış sessizlik olarak dörde ayırarak sınıflandırmıştır. Ancak bu sinıflandırmalar yapılırken işgörenlerin sergilemiş oldukları sessizlik davranışlarının dikkate alındığı görülmektedir (Uçar, 2015: 9). Farklı yazarlar tarafindan farklı zamanlar da oluşturulan bu sinıflandırmalar Tablo 4'de verilmiştir.

\subsubsection{Dyne vd. Tarafindan Yapılan Sessizlik Sinıflandırması}

İlk sessizlik sınıflandırmasını yapan Dyne vd. sessizliği üç ana gruba ayırmıştır. Söz konusu sessizlik sınıflandırmasına aşağıda yer verilmektedir (Dyne vd., 2003: 1365-1368).

\subsubsection{Kabullenici Sessizlik}

Çalışanların bilinçli olarak sessiz kalmalarını, örgütsel konulara karşı ilgisiz olmalarını ifade etmektedir. Kabullenici sessizlik sadece fikirlerin ifade edilmemesi olarak değil aynı zamanda örgüt faaliyetlerinde pasif kalma durumunu da içermektedir. Özellikle çalışanlar kendi fikirlerinin önemsenmediğini ya da örgüt içinde bir fark yaratamadıklarını düşündüklerinde ortaya çıkmaktadır.

\subsubsection{Savunma Amaçlı Sessizlik}

Çalışanların kişisel olarak riskli gördükleri konularda sessiz kalmalarını ifade etmektedir. Bu sessizlik türü genel olarak, çalışanların olumsuz sonuçlarla ilgili sorumlu tutulmak istememelerinden ve kendilerini koruma kaygılarından kaynaklanmaktadır. 
Tablo 4: Sessizlik Sinıflamaları

\begin{tabular}{|c|c|}
\hline Yazar & Boyutlar \\
\hline Dyne; Ang; Botero (2003) & $\begin{array}{l}\text { - Kabullenici Sessizlik (Acquiescent Silence) } \\
\text { - Savunma Amaçli Sessizlik (Defansive Silence) } \\
\text { - Örgüt Yararına Sessizlik (Prosocial Silence) }\end{array}$ \\
\hline $\begin{array}{c}\text { Kish-Gephart; Detert; Trevino; } \\
\text { Edmondson (2009) }\end{array}$ & $\begin{array}{l}\text { - Bilinçli Olmayan Savunmacı Sessizlik (Non-Deliberative } \\
\text { Defensive Silence) } \\
\text { - Plan Odaklı Savunmacı Sessizlik (Schema-Driven Defensive } \\
\text { Silence) } \\
\text { - Bilinçli Savunmacı Sessizlik (Deliberative Defensive Silence) } \\
\text { - Alışılmış Sessizlik (Habituated Silence) }\end{array}$ \\
\hline Pinder; Harlos (2011) & $\begin{array}{l}\text { - İşgören Sükûneti (Employee Quiescent) } \\
\text { - Kabullenici Sessizlik (Employee Acquiescent) }\end{array}$ \\
\hline Kostruk (2012) & $\begin{array}{l}\text { - Taktiksel Sessizlik (Tactical Silence) } \\
\text { - Refleksif Sessizlik (Reflexive Silence) } \\
\text { - Yapisal Sessizlik (Structual Silence) } \\
\text { - Umursamazc1 Sessizlik (Ignorant Silence) }\end{array}$ \\
\hline Knoll; Dick (2013) & $\begin{array}{l}\text { - Kabullenici Sessizlik (Acquiescent Silence) } \\
\text { - Savunmacı Sessizlik (Quiescent Silence) } \\
\text { - Prososyal Sessizlik (Pro-Social Silence) } \\
\text { - Firsatç1 Sessizlik (Opportunistic Silence) }\end{array}$ \\
\hline
\end{tabular}

Kaynak: Tabloda adi geçen kaynaklardan ve Uçar'in (2015) doktora tezinden derlenerek oluşturulmuştur.

\subsubsection{3. Örgüt Yararına Sessizlik}

Çalışanların bilinçli olarak örgüt faydasına olabilecek şekilde sessiz kalmasıdır. Örneğin; çalışanların örgüt ile ilgili birtakım bilgilere sahip olabilir. Çalışanlar bu tip gizli ve özel bilgileri bilinçli şekilde saklayarak örgütün zarar görmesini engelleyebilir.

\subsubsection{Kish-Gephart vd. Tarafindan Yapılan Sessizlik Sinıflandırması}

Kish-Gephart vd. ise, örgütlerde görülen sessizlik halini dört temel grupta ele almışlardır. Yazarlar tarafindan yapılan sınıflandırma aşağıda açıklanmıştır (Kish-Gephart vd., 2009: 171-173).

\subsubsection{Bilinçli Olmayan Savunmacı Sessizlik}

Psikolojik bir geri çekilme olarak ifade edilebilir. Bilinçli olmayan savunmacı sessizlik, bireylerin çok az zamanının olduğu ve konuştuğu konunun ya da sergilediği davranışın kimse tarafından duyulmasını ve görülmesini istemedikleri durumlar da gerçekleşir. $\mathrm{Bu}$ sessizlik türünün temelinde korku vardır. Örneğin, bir işgören yöneticisi ile konuşurken; yöneticinin beklenmedik bir tavır sergilemesi işgöreni korkutabilir ve birtakım endişeler duymasına neden olabilir. Bu tip durumlar da işgören birden sessizleşecek ve bilinçli olmayan bir savunmacı sessizlik gerçekleșecektir.

\subsubsection{Plan Odaklı Savunmacı Sessizlik}

Plan odaklı savunmacı sessizliğin temelinde yatan ana unsur korkular ve geçmiş tecrübelerdir. Çalışanların algıladıkları korku onların sürekli temkinli olmasına neden olacak ve bu korku hali çalışanların sessiz kalmalarına neden olacaktır. Bu tip bir sessizlik anında, genelde korku düşük düzeydedir ancak cevap/tepki vermek için yeterli zaman vardır. Ancak planlı, bilinçli olarak sessizliğin seçilmesi plan odaklı savunmacı sessizlik kavramının ortaya çıkmasına neden olur.

\subsubsection{Bilinçli Savunmacı Sessizlik}

Dyne ve arkadaşlarının (2003) savunma amaçlı sessizlik olarak ifade ettikleri sessizlik türüdür. Zira Kish-Gephart ve arkadaşlarına göre bilinçli savunmacı sessizlik; çalışanların kendilerini olası tehditlerden korumak amacıyla bilinçli olarak sessiz kalmalarını ifade etmektedir. 


\subsubsection{Alışıımış Sessizlik}

Örgütlerde yaşanan sessizlik halinin bir rutin haline gelmesi olarak ifade edilebilir. Bu tip bir sessizlik aynı zamanda öğrenilmiş sessizlik olarak da ele alınabilir. Çünkü bireyler yaşadıkları olumsuz deneyimler ve bazı endişelerden dolayı sessizliği bir davranış haline dönüştürmüş ve bu davranışı tüm çalışma hayatına yansıtmış olabilir.

\subsubsection{Pinder ve Harlos Tarafindan Yapılan Sessizlik Sınıflandırması}

Pinder ve Harlos'a göre sessizlik, işgören sükûneti ve kabullenici sessizlik olarak ikiye ayrılmaktadır (Pinder \& Harlos, 2001: 348-350).

\subsubsection{1. İşgören Sükûneti}

Çalışanın pasif olma durumunu ifade etmektedir. $\mathrm{Bu}$ tip bir sessizlik halinde bir fikir uyuşmazlığının olduğunu söylemek mümkündür. Zira çalışanlar genelde örgüt içindeki durumu değiştirebileceklerinin farkındadırlar ancak bazı sebeplerden dolayı sessiz kalmayı tercih etmektedir. Ancak işgören sükûneti içerisinde olan çalışanlar, mevcut durumu değiştirmek, onları sessizliğe zorlayan engelleri ortadan kaldırmak için en uygun anı beklemektedirler.

\subsubsection{Kabullenici Sessizlik}

Sessizlik halinin davranışa dönüştügü; çalışanların hiçbir şeyi değiştiremeyeceklerine inanarak susmayı tercih ettikleri sessizlik halidir. Pinder ve Harlos'a göre kabullenici sessizlik; bilinçli sessizlikten daha zararlı bir sessizlik halidir ve ortadan kaldırılması ise daha zordur.

\subsubsection{Kostiuk Sessizlik Sınıflandırması}

Kostiuk ise sessizliği dört temel grupta ele alıp incelemiş̧tir (Kostiuk, 2012):

\subsubsection{Taktiksel Sessizlik}

Durum karşısında farklı alternatiflerin olmasına karşın, çalışanlar tarafindan en iyi çıkış yolunun sessiz kalmak olarak değerlendirilmesi ile ortaya çıkmaktadır. Çoğu zaman çalışanlar kötü durumlara düşmemek ya da daha fazla kazanç elde edebilmek adına birtakım bilgileri gizlemeyi tercih etmektedirler.

\subsubsection{Refleksif Sessizlik}

Gelişen duruma ya da ortaya çıkan tehdide göre çalışanların bilinçsiz bir şekilde, kendilerini korumak için, sessiz kalmaları olarak ifade edilebilir.

\subsubsection{Yapısal Sessizlik}

Teknik ve çevresel nedenlerden dolayı çalışanların birbirleri ile iletişim kuramamalarından kaynaklanmaktadır.

\subsubsection{Umursamazcı Sessizlik}

Çalışanların işletme ile ilgili durumlarda etkinliklerini kaybettiklerini düşündükleri zaman ortaya çıkmaktadır. Bu durumda, çalışanlar mevcut sorunlarla ilgilenmemekte, herhangi bir çözüm yolu arayışına girmemektedir.

\subsubsection{Knoll ve Dick Tarafindan Yapılan Sessizlik Sinıflandırması}

Knoll ve Dick ise 2013 yılında yaptıkları bir çalışma da sessizliği dört ana gruba ayırmışlardır. Söz konusu sınıflandırma aşağıdaki gibidir (Knoll \& Dick, 2013: 350-352):

\subsubsection{Kabullenici Sessizlik}

Değişim umudunu yitiren çalışanların sessizlik halidir. Bu tip bir sessizlik içerisinde olan bireyler değişim umutlarını yitirdikleri için değişim yapabilecek eylemlerden de uzak durmaktadır.

\subsubsection{Savunmacı Sessizlik}

Söz konusu sorunlar ile ilgili farklı alternatifler ve çözüm yolları hakkında fikir sahibi olan bireylerin sessizliği kendilerini olumsuz durumlardan korumak amaciyla tercih etmeleri olarak ifade edilebilir. $\mathrm{Bu}$ sessizlik türünde, çalışanlar sessizliği stratejik bir eylem olarak ele almakta ve kendileri için en iyi durumun sessizlik olduğuna inanmaktadırlar.

\subsubsection{Prososyal Sessizlik}

Çalışanların, diğer çalışanların da iyiliğini düşünerek bazı fikir ya da bilgileri gizlemeleridir. Bu durumda çalışanlar hem örgüt hem de örgüt çalışanlarının faydasını düşünmekte, herkes için en iyi durumun sessiz kalmak olduklarına inandıklarında sessizliği tercih etmektedirler.

\subsubsection{Fırsatçı Sessizlik}

Çalışanların bir takım bilgi ve tecrübelerini stratejik olarak gizlemeleri olarak ifade edilebilir. $\mathrm{Bu}$ sessizlik halinde, çalışanlar söz konusu bilgileri kendilerine avantaj sağlamak ya da daha fazla gelir elde etmek için gizlemektedirler. 


\section{VERİ TOPLAMA ARACI VE YÖNTEMİ}

$\mathrm{Bu}$ çalışma, Türkiye'de sağlık alanında yapılmış işgören/çalışan sessizliği ve örgütsel sessizlik ile ilgili araştırmalara yönelik bir yazın incelemesidir. Çalışma kapsamında, uygun veri kaynakları kullanılarak işgören sessizliği ve örgütsel sessizlik ile ilgili yapılan araştırmalar belirlenmiş ve belirlenen ölçütler doğrultusunda elemeler yapılmıştır. Elemeler sonucunda değerlendirilmeye alınan araştırmalar; yazarı, yayın yılı, örneklem seçimi, araştırma türü ve elde edilen sonuçları bakımından incelenmiştir.

İşgören sessizliği ve örgütsel sessizlik ile ilgili Türkiye'de ve sağlık alanında yapılan araştırmaların tamamına ulaşabilmek için arama motoru olarak; YÖK tez arama merkezi, Ulakbim ve Google Akademik kullanılmış ve aranan kelimeler, kriterler ve araștırma sınırlılıkları Tablo 5'de verilmiştir.

Tablo 5'de belirtilen anahtar kelimeler ve arama kriterleri doğrultusunda yapılan tarama sonucu 33 çalışma tespit edilmiştir. Ancak 6 tezin erişimi yazarı tarafından kısıtlandığı için çalışmaya 8 tez, 19 makale dâhil edilmiştir. Ulaşılan ve çalışma kapsamina alınan tez ve makaleler Tablo 6 ve Tablo 7'de verilmiştir.

\section{BULGULAR}

$\mathrm{Bu}$ bölümde değerlendirmeye alınan araştırmalara ilişkin bulgular yer almaktadır. Yapılan tarama sonucunda 19 makale, 1 doktora tezi ve 7 yüksek lisans tezi olmak üzere toplam 27 çalışmaya ulaşılmıştır. Bu çalışmaların 4'ü işgören/çalışan sessizliği, 23'ü ise örgütsel sessizlik başlığ 1 altında yayımlanmıştır.

İşgören/çalışan sessizliği konusunda yapılan çalışmaların 2'si yüksek lisans tezi iken 2'si araştırma makalesidir. Ancak bu makalelerin 2'si de İngilizce olup, işgören sessizliği konusunda belirlenen kriterlere uygun Türkçe makale tespit edilememiştir. Örgütsel sessizlik ile ilgili ulaşılan çalıșmaların ise, 5'i yüksek lisans tezi, 1'i doktora tezi, 17'si ise araştırma makalesidir. (Bkz. Tablo 8)

Çalışma kapsamında ele alınan araştırmaların yıllara ve türlerine göre dağılımı incelendiğinde; Türkiye'de sağlık alanında yapılmış örgütsel sessizlik konusu ile ilgili ilk çalışma 2012 yılında yapılmıștır. Yıllar itibari ile her yıl en az bir lisansüstü tezi olduğu görülmektedir ancak bu tezlerden 6'sına erişim kısıtlaması olduğu için ulaşılamamaktadır. Ayrıca bu tezlerden bir tanesi doktora tezi olup 2014 yılında yazılmıştır. 2014 ve sonrasında yapılan çalışmaların yoğunlaştığı görülmekle birlikte bu alanda ilk makale 2012 yılında yazılmıştır. İşgören / çalışan sessizliği konusunda ise; ilk çalıșma bir araștırma makalesidir ve 2013 yılında yapılmıștır. Bu konuda yayımlanmıș bir diğer makale ise Alparslan, Ali \& Erdem tarafından 2015 yılında yapılmıştır. Ayrıca bu konuda 2016 yılında 2 yüksek lisans tezi yazılmıştır. (Bkz. Grafik 1)

Tablo 5: Araştıma Tarama Kriterleri

\begin{tabular}{|c|c|}
\hline Veri Tabanlan & $\begin{array}{l}\text { - YÖK Tez Arama Merkezi } \\
\text { - Ulakbim } \\
\text { - Google Akademik } \\
\text { - Sciencedirect } \\
\text { - Scopus } \\
\text { - Ebscohost }\end{array}$ \\
\hline Anahtar Kelimeler & $\begin{array}{l}\text { - Işgören Sessizliği } \\
\text { - Çalışan Sessizliği } \\
\text { - Örgütsel Sessizlik } \\
\text { - Employee Silence } \\
\text { - Organizational Silence }\end{array}$ \\
\hline Arama Kriterleri & $\begin{array}{l}\text { - Araştırmanın Türkiye'de yapılmış olması. } \\
\text { - Türç̧e ya da Ingilizce yazılmı̧̧ olması. } \\
\text { - Sağlik alanında veya hemş̧ireler, hekimler ya da sağllk çalı̧anları üzerinde yapılmış olması. } \\
\text { - Mart } 2017 \text { 'ye kadar yayımlanmış bir araştımma olmass. } \\
\text { - Tez ya da yayımlanmış makale olması. }\end{array}$ \\
\hline
\end{tabular}


Tablo 6: Çalışma Kapsamina Alınan İşgören/Çalışan Sessizliği Konulu Çalışmalar

\begin{tabular}{|c|c|c|c|c|c|c|}
\hline No & Yazar(lar)/Tarih & Araștırma İsmi & Türü & Örneklemi & $\begin{array}{c}\text { Veri Toplama } \\
\text { Yöntemi }\end{array}$ & Sonuç \\
\hline 1 & Deniz vd., 2013 & $\begin{array}{l}\text { The Relationship } \\
\text { Between Employee } \\
\text { Silence and } \\
\text { Organizational } \\
\text { Commitment in a Private } \\
\text { Healthcare Company }\end{array}$ & Araştırma & $\begin{array}{c}\text { Sağlik } \\
\text { Çalışanları }\end{array}$ & $\begin{array}{c}\text { Örgütsel } \\
\text { Sessizlik Ölçeği }\end{array}$ & $\begin{array}{l}\text { Örgütsel sessizlik konusunda } \\
\text { giderek artan bir farkındalık } \\
\text { olmasına rağmen; örgütsel } \\
\text { bağlilik ile ilgili tutarlı bir } \\
\text { bulgu bulunamamıştır. }\end{array}$ \\
\hline 2 & $\begin{array}{l}\text { Alparslan vd., } \\
2015\end{array}$ & $\begin{array}{l}\text { Reasons for Employee } \\
\text { Silence Behavior: } \\
\text { Developing and } \\
\text { Validating a Scale for } \\
\text { Nurses }\end{array}$ & Araştırma & Hemşireler & $\begin{array}{l}\text { Saha } \\
\text { Araştırmasi; } \\
\text { Odak Grup } \\
\text { Çalışması }\end{array}$ & $\begin{array}{l}5 \text { boyut ve } 26 \text { maddeden } \\
\text { oluşan bir ölçek } \\
\text { geliştirilmiştir. }\end{array}$ \\
\hline 3 & Akarsu, 2016 & $\begin{array}{l}\text { Hemşirelerde Çalışan } \\
\text { Sessizliği ve İ̧ Doyumu } \\
\text { Arasındaki İlişki }\end{array}$ & $\begin{array}{l}\text { Y. Lisans } \\
\text { Tezi }\end{array}$ & Hemşireler & $\begin{array}{l}\text { Çalışan } \\
\text { Sessizlik } \\
\text { Davranışi } \\
\text { Ölçeği; } \\
\text { Iş Tatmini } \\
\text { Ölçeği }\end{array}$ & $\begin{array}{l}\text { Sessizlik üzerinde; cinsiyetin, } \\
\text { medeni durumun ve çalışma } \\
\text { ortamının etkili olduğu } \\
\text { görülmüştür. }\end{array}$ \\
\hline 4 & Kilıçarslan, 2016 & $\begin{array}{l}\text { Yönetici Davranışlarının } \\
\text { İ̧̧ören Sessizliğine } \\
\text { Etkisi: Sağlık Sektöründe } \\
\text { Çalışanlar Üzerine Bir } \\
\text { Uygulama }\end{array}$ & $\begin{array}{l}\text { Y. Lisans } \\
\text { Tezi }\end{array}$ & $\begin{array}{c}\text { Sağlik } \\
\text { Çalışanları }\end{array}$ & $\begin{array}{c}\text { Örgütsel } \\
\text { Sessizlik Ölçeği }\end{array}$ & $\begin{array}{l}\text { Hemşireler doktorlara göre } \\
\text { daha sessizdir ve gelir düzeyi } \\
\text { sessizliği etkilemektedir. }\end{array}$ \\
\hline
\end{tabular}

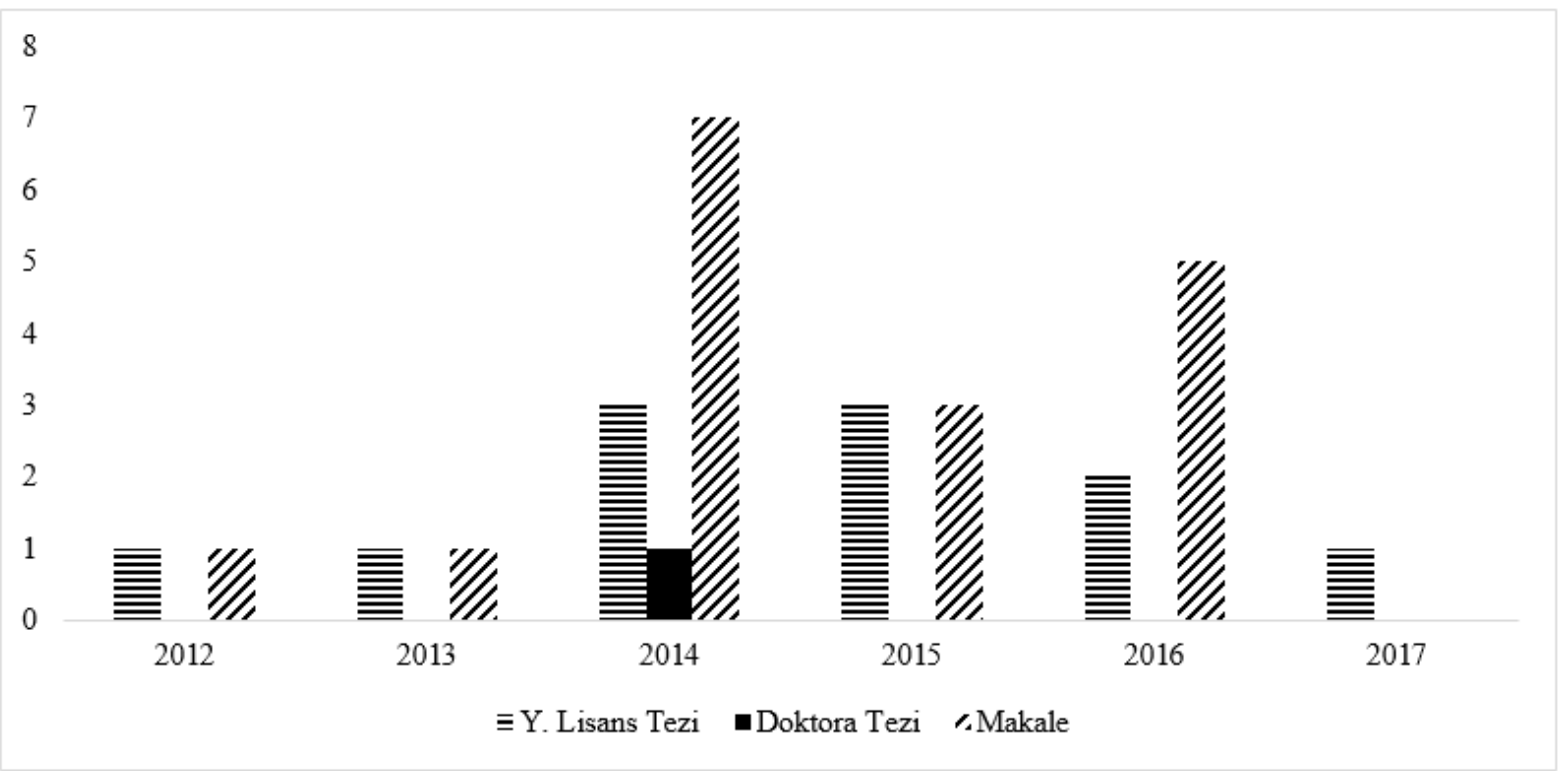

Grafik 1: Araştırma Kapsamına Alınan Örgütsel Sessizlik Konulu Araştırmaların Türlere ve Yıllara Göre Dağılımları 
Tablo 7: Çalışma Kapsamına Alınan Örgütsel Sessizlik Konulu Çalış̧malar

\begin{tabular}{|c|c|c|c|c|c|c|}
\hline No & Yazar(lar)/Tarih & Araștırma İsmi & Türü & Örneklemi & Veri Toplama Yöntemi & Sonuç \\
\hline 1 & $\begin{array}{l}\text { Yalçın ve Baykal, } \\
2012\end{array}$ & $\begin{array}{l}\text { Özel Hastanelerde Görevli Hemşirelerin Sessiz } \\
\text { Kaldığı Konular ve Sessiz Kalma Nedenleriyle } \\
\text { tliş̧kili Faktörler }\end{array}$ & Araşturma & Hemşireler & $\begin{array}{l}\text { Örgütsel Sessizlik } \\
\text { Ölçeği }\end{array}$ & $\begin{array}{l}\text { Yönetici hemşirelerin hem üstleri hem de astları ile } \\
\text { rahat bir konuşma ortamı sağlama çalışmaları, } \\
\text { hemşireler için daha iyi bir çalışma ortamı yaratmaya } \\
\text { katkı sağlayabilir. }\end{array}$ \\
\hline 2 & Kilinç, 2012 & $\begin{array}{l}\text { Hekim ve Hemşirelerde Örgütsel Vatandaşlık } \\
\text { Davranışı, Örgütsel Sessizlik, Çalışan Performansı } \\
\text { Ve Aralarındaki Ilişkinin Incelenmesi }\end{array}$ & $\begin{array}{l}\text { Y. Lisans } \\
\text { Tezi }\end{array}$ & $\begin{array}{l}\text { Hekim Ve } \\
\text { Hemşireler }\end{array}$ & $\begin{array}{l}\text { Örgütsel Vatandaşlık } \\
\text { Davranışı Ölçeği; } \\
\text { Örgütsel Sessizlik } \\
\text { Ölçeği; Çalı̧şan Ölçeği }\end{array}$ & $\begin{array}{l}\text { Örgüt yararına sessizlik ile çalı̧an performansı } \\
\text { arasındaki ilişsinin pozitif yönde anlamlı olduğu, } \\
\text { kabul edilmiş sessizlik ve savunma amaçlı sessizliğin } \\
\text { çalışan performansına katkı yapmadığı görülmüştür. }\end{array}$ \\
\hline 3 & Tayfun ve Çatır, 2013 & $\begin{array}{l}\text { Örgütsel Sessizlik ve Çalışanların Performansları } \\
\text { Arasındaki İlişki Üzerine Bir Araşurma }\end{array}$ & Araşturma & Hemşire & $\begin{array}{l}\text { Örgütsel Sessizlik } \\
\text { Ölçeği }\end{array}$ & $\begin{array}{l}\text { Hemşirelerin kabul edilen sessizlik, savunma amaçlı } \\
\text { sessizlik ve seslilik, örgüt yararına sessizlik ve } \\
\text { seslilik ile çalışanların performansı arasında bir ilişki } \\
\text { bulunmuştur. }\end{array}$ \\
\hline 4 & Eren, 2013 & $\begin{array}{l}\text { Liderlik ve Örgütsel Sessizlik: Haseki Eğitim ve } \\
\text { Araştırma Hastanesi'nde Çalışma Örneği }\end{array}$ & $\begin{array}{l}\text { Y. Lisans } \\
\text { Tezi }\end{array}$ & $\begin{array}{c}\text { Sağlık } \\
\text { Çalışanları }\end{array}$ & Anket & $\begin{array}{l}\text { Yöneticilerin sergiledikleri liderlik davranışlarından } \\
\text { sessizlik üzerinde etkisi olduğu ortaya konulmuştur. }\end{array}$ \\
\hline 5 & Çınar vd., 2013 & $\begin{array}{l}\text { The Relationship Between Organizational Silence } \\
\text { and Organizational Citizenship Behavior: a } \\
\text { Survey Study in the Province of Erzurum, Turkey }\end{array}$ & Araşturma & $\begin{array}{l}\text { Ilaç Firması } \\
\text { ve Hastane } \\
\text { Çalışanları }\end{array}$ & $\begin{array}{l}\text { Örgütsel Sessizlik } \\
\text { Ölçeği }\end{array}$ & $\begin{array}{l}\text { Örgütsel sessizlik ile örgütsel vatandaşlik davranışı } \\
\text { arasında güçlü bir iliş̧ki olduğu gözlemlenmiştir. }\end{array}$ \\
\hline 6 & Toker vd., 2014 & $\begin{array}{l}\text { The Factors Affecting the Organizational Silence } \\
\text { of The Nurses and The Other } \\
\text { Clinical-Care Providers in Turkey }\end{array}$ & Araştırma & $\begin{array}{c}\text { Sağlik } \\
\text { Çalışanlanı }\end{array}$ & $\begin{array}{l}\text { Örgütsel Sessizlik } \\
\text { Ölçeği }\end{array}$ & $\begin{array}{l}\text { Sağlik çalışanları arasındaki örgütsel sessizliğin } \\
\text { çalışanlar arasındaki iletişimi etkileyen önemli bir } \\
\text { unsur olduğu tesp̧it edilmiştir. }\end{array}$ \\
\hline 7 & Erigüç vd., 2014 & $\begin{array}{l}\text { The Causes and Effects of The Organizational } \\
\text { Silence: on which issues The Nurses Remain } \\
\text { Silent? }\end{array}$ & Araşturma & Hemşireler & $\begin{array}{l}\text { Örgütsel Sessizlik } \\
\text { Ölçeği }\end{array}$ & $\begin{array}{l}25 \text { ve daha genç yaşlardaki hemşireler ile kadın } \\
\text { hemşirelerin daha sessiz kaldığı bulunmuştur. }\end{array}$ \\
\hline 8 & Erigüç vd., 2014 & $\begin{array}{l}\text { Bir Devlet Hastanesinde Hemşirelerde Örgütsel } \\
\text { Sessizlik Üzerine Bir Araşturma }\end{array}$ & Araşturma & Hemşireler & $\begin{array}{l}\text { Örgütsel Sessizlik } \\
\text { Ölçeği }\end{array}$ & $\begin{array}{l}\text { En az sessiz kalınan konunun taciz olaylanı olduğu } \\
\text { bulunmuştur. }\end{array}$ \\
\hline 9 & Erigüç vd. 2014 & $\begin{array}{l}\text { Organizational Silence among Nurses: A Study of } \\
\text { Structural Equation Modeling }\end{array}$ & Araşturma & Hemşireler & $\begin{array}{l}\text { Örgütsel Sessizlik } \\
\text { Ölçeği }\end{array}$ & $\begin{array}{l}\text { Örgütsel sessizlik ölçeğinin hemşireler üzerinde } \\
\text { kullanımın uygun olduğu bulunmuştur. }\end{array}$ \\
\hline 10 & Demiralay, 2014 & $\begin{array}{l}\text { Hekimlerde Örgütsel Sessizliğin Yapısal Eşitlik } \\
\text { Modeli İle İncelenmesi }\end{array}$ & $\begin{array}{l}\text { Doktora } \\
\text { Tezi }\end{array}$ & Hekimler & $\begin{array}{l}\text { Örgütsel Sessizlik } \\
\text { Ölçeği; Örgütsel Adalet } \\
\text { Algısı Ölçeği; Algıılanan } \\
\text { Katulimcı İlim Ölçeği }\end{array}$ & $\begin{array}{l}\text { Bireyin, kendini koruma içgüdüsüyle ortaya çıkan } \\
\text { savunmacı sessizlik davranış1, hekimlerin işlemsel } \\
\text { adalet ve etkileşim adalet algıları arttıkça } \\
\text { azalmaktadır. }\end{array}$ \\
\hline 11 & Çiriş, 2014 & $\begin{array}{l}\text { Üniversite Hastanesinde Görev Yapan Yönetici } \\
\text { Hemşirelerin Sessiz Kaldiğ1 Konular ve } \\
\text { Sessizliğini Etkileyen Faktörler }\end{array}$ & $\begin{array}{l}\text { Y. Lisans } \\
\text { Tezi }\end{array}$ & Hemşireler & $\begin{array}{l}\text { Örgütsel Sessizlik } \\
\text { Ölçeği }\end{array}$ & $\begin{array}{l}\text { Sessizliğe en az neden olan konunun "tecrübe } \\
\text { eksikliği" olduğu, en öncelikli sessizlik nedenleri ise } \\
\text { "'yönetsel ve örgütsel nedenler ile izolasyon } \\
\text { korkusu" olduğu saptanmıştır. }\end{array}$ \\
\hline 12 & Çaylak, 2014 & $\begin{array}{l}\text { Hemşirelerde Örgütsel Sessizlik İle Örgütsel } \\
\text { Sinizm ve İşten Ayrilma Niyeti Arasındaki İlişki }\end{array}$ & $\begin{array}{l}\text { Y. Lisans } \\
\text { Tezi }\end{array}$ & Hemşireler & $\begin{array}{c}\text { Örgütsel Sessizlik } \\
\text { Ölçeği, } \\
\text { Örgütsel Sinizm Ölçeği; } \\
\text { İşten Ayrilma Niyeti } \\
\text { Ölçeği }\end{array}$ & $\begin{array}{l}\text { Örgütsel sessizlik nedenleri ile örgütsel sinizmin } \\
\text { hemşirelerin işten ayrilma niyetleri üzerinde etkili } \\
\text { olduğunu sonucuna ulaşıılmıştr. }\end{array}$ \\
\hline 13 & Aktaş ve Şimşek, 2014 & $\begin{array}{l}\text { Örgütsel Sessizlik İle Algılanan Bireysel } \\
\text { Performans, Örgüt Kültürü Ve Demografik } \\
\text { Değişkenler Arasındaki Etkileşim }\end{array}$ & Araştırma & Hemşireler & $\begin{array}{c}\text { Örgütsel Sessizlik } \\
\text { Ölçeği; Örgüt Kültürü } \\
\text { Ölçeği }\end{array}$ & $\begin{array}{l}\text { Algilanan bireysel performans ile kabullenici } \\
\text { sessizlik arasında negatif ve ilişkisel sessizlik ise } \\
\text { pozitif iliş̧kiliyken savunmacı sessizlik ile ilişkili } \\
\text { değildir. }\end{array}$ \\
\hline 14 & Kilınç ve Ulusoy 2014 & $\begin{array}{l}\text { Investigation of Organizational Citizenship } \\
\text { Behavior, Organizational Silence and Employee } \\
\text { Performance at Physicians and Nurses, and The } \\
\text { Relationship Among Them }\end{array}$ & Araşturma & $\begin{array}{l}\text { Doktor ve } \\
\text { Hemşireler }\end{array}$ & $\begin{array}{c}\text { Örgütsel Sessizlik } \\
\text { Ölçeği; Örgütsel } \\
\text { Vatandaşlık Ölçeği; } \\
\text { Çalışan Performansı Ö. }\end{array}$ & $\begin{array}{l}\text { Örgütsel sessizlik, çalışan performansı ve örgütsel } \\
\text { vatandaşlık arasında anlamlı bir iliş̧ki bulunmuştur. }\end{array}$ \\
\hline 15 & Yeşilaydın vd., 2015 & $\begin{array}{l}\text { Sağllk Personelinin Örgütsel Sessizlik } \\
\text { Nedenlerinin Belirlenmesi: Özel Hastane Örneği }\end{array}$ & Araştırma & $\begin{array}{l}\text { Sağlik } \\
\text { Çalışanları }\end{array}$ & $\begin{array}{l}\text { Örgütsel Sessizlik } \\
\text { Nedenleri Anketi }\end{array}$ & $\begin{array}{l}\text { Çalışanların en çok yönetsel ve örgütsel nedenlerden } \\
\text { en az ise tecrübe eksikliğinden dolayı sessiz kaldığı } \\
\text { hulınmııetır }\end{array}$ \\
\hline 16 & Budak, 2015 & $\begin{array}{l}\text { Kamu Kurumlarında Örgütsel Sessizlik, Etik: } \\
\text { thelim ve Yoonetim Tarzlarn Alt Boyutlan } \\
\text { flişkilerinin fncelenmesi: Örnek Bir Uygulama }\end{array}$ & $\begin{array}{l}\text { Y. Lisans } \\
\text { Tezi }\end{array}$ & $\begin{array}{l}\text { Sağlak } \\
\text { Çalı̧anlan }\end{array}$ & $\begin{array}{l}\text { Örgütsel Sessizlik } \\
\text { Anketi; Orgütsel } \\
\text { Sessizlik Ölçeği }\end{array}$ & 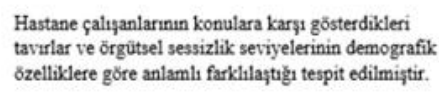 \\
\hline 17 & Bayın vd., 2015 & $\begin{array}{l}\text { Hemşirelerde Örgütsel Sessizlik Nedenlerinin } \\
\text { Belirlenmesi }\end{array}$ & Aragturma & Hemģireler & $\begin{array}{l}\text { Orgütsel Sessizlik } \\
\text { Nedenleri Anketi }\end{array}$ & $\begin{array}{l}\text { Sessiz kalma konusunda yōnetsel ve örgūtsel } \\
\text { nedenlerin daha çok oldugutu tespit edilmiştir. }\end{array}$ \\
\hline 18 & Urek vd., 2016 & 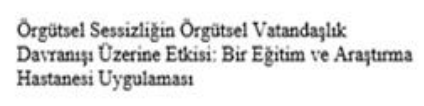 & Aragterma & $\begin{array}{l}\text { Sağlth } \\
\text { Çalyģans }\end{array}$ & $\begin{array}{l}\text { Orgütsel Sessizlik } \\
\text { Ölçę̧i; } \\
\text { Orgütsel Vatandaģlik } \\
\text { Davranışı Ölçeği }\end{array}$ & $\begin{array}{l}\text { Çalı̧anların en çok örgütlerine fayda sağlamak için } \\
\text { en az ise kendilerini korumak için sessiz kaldığs } \\
\text { bulunmugtur. Çalıganları genellikle sessiz } \\
\text { kalmadikları bulunmugtur. }\end{array}$ \\
\hline
\end{tabular}


Tablo 7: Çalışma Kapsamına Alınan Örgütsel Sessizlik Konulu Çalı̧̧malar (Devam)

\begin{tabular}{|c|c|c|c|c|c|c|}
\hline 19 & $\begin{array}{l}\text { Yeșilaydın vd, } \\
2016\end{array}$ & $\begin{array}{l}\text { Örgütsel Sessizliğin Nedenleri: Kamu } \\
\text { Hastaneleri Çalı̧anlan Uzerine Bir } \\
\text { Araşturma }\end{array}$ & Araştırma & $\begin{array}{l}\text { Sağllk } \\
\text { Çalışanlanı }\end{array}$ & $\begin{array}{l}\text { Örgütsel Sessizlik } \\
\text { Nedenleri Anketi }\end{array}$ & $\begin{array}{l}\text { Çalışanların en çok yönetsel ve örgütsel } \\
\text { nedenlerden dolayı sessiz kaldığı tespit } \\
\text { edilmiştir. }\end{array}$ \\
\hline 20 & $\begin{array}{l}\text { Yalçınsoy ve } \\
\text { Zincirkıran, } 2016\end{array}$ & $\begin{array}{l}\text { Örgüt Kültürü ve Örgüt İkliminin Örgütsel } \\
\text { Sessizlik Uzerine Etkisinin Analizi }\end{array}$ & Araşturma & $\begin{array}{c}\text { Sağllk } \\
\text { Çalışanlanı }\end{array}$ & $\begin{array}{l}\text { Örgüt Kültürü Ölçeği; } \\
\text { Orgüt Iklimi Olçeğ; } \\
\text { Örgütsel Sessizlik } \\
\text { Ölçeği }\end{array}$ & $\begin{array}{l}\text { Örgüt kültürü, örgüt iklimi ve örgütsel sessizlik } \\
\text { arasmnda anlamlı bir iliş̧i bulunmuştur. }\end{array}$ \\
\hline 21 & Yurdakul vd., 2016 & $\begin{array}{l}\text { The Organisational Silence of Midwives and } \\
\text { Nurses: Reasons and Results }\end{array}$ & Araşturma & $\begin{array}{c}\text { Ebe ve } \\
\text { Hemşireler }\end{array}$ & $\begin{array}{l}\text { Örgütsel Sessizlik } \\
\text { Olçeği }\end{array}$ & $\begin{array}{l}\text { Örgütsel sessizlik halinin ebe ve hemşirelerde } \\
\text { yaygin görüldüğu bulunmuştur. }\end{array}$ \\
\hline 22 & $\begin{array}{l}\text { Çaylak, Altuntas } \\
2016\end{array}$ & $\begin{array}{l}\text { Organizational Silence among Nurses: The } \\
\text { Impact on Organizational Cynicism and } \\
\text { Intention to Leave Work }\end{array}$ & Arasturma & Hemşire & $\begin{array}{l}\text { Örgütsel Sessizlik } \\
\text { Ölçeği }\end{array}$ & $\begin{array}{l}\text { Örgütsel sessizlik ve örgütsel sinizmin } \\
\text { hemsirelerin işten aynlması üzerinde etkili } \\
\text { olduğunu bulmuştur. }\end{array}$ \\
\hline 23 & Saygli vd. & $\begin{array}{l}\text { Sağllk Çalışanlarını Örgütsel Sessizlik ve } \\
\text { Çalışan Performansı Düzeylerinin } \\
\text { Belirlenmesi }\end{array}$ & Araşturma & $\begin{array}{c}\text { Sağllk } \\
\text { Çalışanlanı }\end{array}$ & $\begin{array}{l}\text { Örgütsel Sessizlik } \\
\text { Olçeği }\end{array}$ & $\begin{array}{l}\text { Calışanların örgütsel sessizlik düzeyleri ile } \\
\text { çalıştılları birimler, mesleki durumlan ve } \\
\text { çalışma süreleri arasında istatistiksel olarak } \\
\text { anlamlı bir iliş̧i bulunmuştur. }\end{array}$ \\
\hline
\end{tabular}

Tablo 8: Çalışma Kapsamındaki Araştırmaların Konu ve Türlerine Göre Dağılımları

\begin{tabular}{ccc|cc|cc} 
& \multicolumn{2}{c|}{ Y Lisans Tezi } & \multicolumn{2}{c|}{ Doktora Tezi } & \multicolumn{2}{c}{ Makale } \\
\cline { 2 - 7 } Konu* $^{*}$ & Sayı & $\%$ & Sayı & $\%$ & Sayı & $\%$ \\
\hline İsgören/Çalışan Sessizliği & 2 & 25,5 & 0 & 0,00 & 2 & 10,6 \\
Örgütsel Sessizlik & 5 & 71,5 & 1 & 100,0 & 17 & 89,4 \\
Toplam & 7 & 100,0 & 1 & 100,0 & 19 & 100,0 \\
\hline
\end{tabular}

* Değerlendirmeye alınan araştırmalar başliklarına göre sınıflandırılmıştır.

Tablo 9: Çalışma Kapsamındaki Makalelerde Kullanılan Anahtar Kelimeler

\begin{tabular}{lcc}
\hline Anahtar Kelimeler & Sayı & $\%$ \\
\hline Örgütsel sessizlik & 19 & 28,2 \\
$\begin{array}{l}\text { Hemşire (hemşire, hemşirelik, hemşirelerde sessizlik, } \\
\text { hemşirelikte yönetim) }\end{array}$ & 10 & 14,7 \\
Hastane & 4 & 5,8 \\
Sağlık çalışanları & 3 & 4,4 \\
Sağlık kurumları yönetimi/ sağlık yönetimi & 3 & 4,4 \\
Performans (Görev performansı, Bağlamsal Performans) & 5 & 7,4 \\
Örgüt kültürü & 2 & 2,8 \\
İsgören sessizliği & 2 & 2,8 \\
Sessizlik & 3 & 4,4 \\
Bağlılık (Örgütsel bağlılık, duygusal bağlilık) & 2 & 2,8 \\
Diğer & 15 & 22,3 \\
Toplam & $\mathbf{6 7}$ & $\mathbf{1 0 0 , 0}$ \\
\hline
\end{tabular}


Tablo 10: Çalışma Kapsamındaki Araştırmaların Örneklem Seçimleri

\begin{tabular}{lcc|cc} 
& \multicolumn{2}{c|}{ Issgören Sessizliği* } & \multicolumn{2}{c}{ Örgütsel Sessizlik* } \\
\cline { 2 - 5 } Örneklem & Sayı & \% & Sayı & \% \\
\hline Sağlık Personeli & 2 & 50.0 & 12 & 52,8 \\
Hemşire & 2 & 50.0 & 10 & 43,4 \\
Hekim & - & - & 1 & 4,3 \\
Toplam & $\mathbf{4}$ & $\mathbf{1 0 0 , 0}$ & $\mathbf{2 3}$ & $\mathbf{1 0 0 , 0}$ \\
\hline
\end{tabular}

* Değerlendirmeye alınan araştırmalar başlıklarına göre sınıflandırılmıştır.

Tablo 11: Araştırmalar Kullanılan Soru Formlarının Dağılımı

\begin{tabular}{|c|c|c|c|c|}
\hline Geliștiren/ler & Uyarlama/lar & Soru Formalarn & Say1 & $\%$ \\
\hline \multirow{4}{*}{ Dyne vd. (2003) } & Taşkıran (2010) & Örgütsel Sessizlik Ölçeği & 1 & 3,9 \\
\hline & $\begin{array}{l}\text { Şehitoğlu ve Zehir } \\
\text { (2010) }\end{array}$ & Örgütsel Sessizlik Ölçeği & 2 & 7,6 \\
\hline & Erdoğan (2010) & Örgütsel Sessizlik Ölçeği & 1 & 3,9 \\
\hline & Araştırmac1 & Örgütsel Sessizlik Ölçeği & 2 & 7,6 \\
\hline Çakıc1 $(2007 ; 2010) *$ & & Örgütsel Sessizlik Ölçeği & 8 & 30,7 \\
\hline Çakıcı (2008) & & $\begin{array}{l}\text { Örgütsel Sessizlik Nedenleri } \\
\text { Ölçeği }\end{array}$ & 6 & 23,1 \\
\hline Alparslan (2010) & & Örgütsel Sessizlik Ölçeği & 3 & 11,5 \\
\hline $\begin{array}{l}\text { Knoll ve Dick } \\
(2013)\end{array}$ & Araştırmacı & Örgütsel Sessizlik Ölçeği & 1 & 3,9 \\
\hline $\begin{array}{l}\text { Kahveci ve } \\
\text { Demirtaș (2013) }\end{array}$ & & Örgütsel Sessizlik Ölçeği & 1 & 3,9 \\
\hline Soru formu araștırma & c1 tarafindan oluşturul & & 1 & 4 \\
\hline Toplam & & & $26^{1}$ & 100,0 \\
\hline
\end{tabular}

* Çakıcı'nın geliștirmiş olduğu Örgütsel Sessizlik Ölçeği 2010 yılında yayımlanmıștır.

Tablo 9'da görüldüğü üzere makalelerde en çok kullanılan anahtar kelimeler verilmiştir. Değerlendirmeye alınan 19 makalede en çok kullanılan anahtar kelime \% 28,2 ile "örgütsel sessizlik" kavramıdır. Ayrıca araştırmalar sağlık alanında yapıldı̆̆ı için hastane, sağlık çalışanları, hemşire, performans ve sağlık kurumları yönetimi kavramlarının da sıklıkla kullanıldığı görülmektedir.

Analiz sonucunda çalışma kapsamına alınan araştırmaların çalışma grupları incelendiğinde ise; işgören sessizliği konusunda yapılan 4 çalışmanın 2'sinde hemşireler çalışma kapsamına alınırken 2'sinde ise birden fazla meslek grubunun çalışmaya dâhil edildiği görülmektedir. Ancak yapılan taramalar sonucunda, sadece hekimlere yönelik yapılmış işgören sessizliği konulu herhangi bir çalışma tespit edilememiştir. Örgütsel sessizlik konusunda ise; çalışmaların \% 52,8'i (12) birden fazla meslek grubu üzerine yap1lırken, \% 43,4'ü (10) ise hemşireler, \% 4,3'ü ise hekimler üzerinde yapılmıştır. (Bkz. Tablo 10)

Tablo 11'de araştırmalarda kullanılan soru formlarına yer verilmiştir. Çalışma kapsamında ele alınan 27 araştırmanın \% 23'ünde (6) Dyne ve arkadaşların tarafından 2003 yılında geliştirilen “Örgütsel Sessizlik Ölçeği”" kullanılmıştır. Ancak Dyne ve arkadaşlarının geliştirdiği bu ölçek farklı araştırmacılar tarafından farklı çalışmalar da Türkçe' ye çevrilmiş ve geçerlik, güvenirlik çalışmaları 
yapılmıştır. Değerlendirmeye alınan 2 çalışmada ise söz konusu ölçek araştırmacılar tarafindan Türkçe uyarlama çalışmaları yapılarak kullanılmıştır. Çalışmaların \% 23'ünde ise Çakıcı'nın 2008 yılında geliştirdiği "Örgütsel Sessizlik Nedenleri” ölçeği kullanılmıştır. Ayrıca bu çalışmalardan 1'sinde ise (yüksek lisans tezi) sessizliği ölçmek için, araştırmacı tarafindan yazın incelemesi yapılarak oluşturulmuş soru formları kullanılmıştır.

\section{TARTIŞMA VE SONUÇ}

Sessizlik kavramı ilk kez 1970 yılında Hirschman tarafından tanımlanmıştır. Fakat işgören sessizliği ve örgütsel sessizlik kavramları oldukça yeni kavramlar olarak değerlendirilebilir. Sağlık alanında yapılan işgören sessizliği ve örgütsel sessizlik kavramlarına yönelik çalışmaların 2010 yılı sonrasında yapılmaya başlandığı görülmektedir. Ayrıca hala işgören sessizliği ve örgütsel sessizlik kavramlarının tam olarak tanımlanamadığı, birbirlerinin yerine kullanıldı̆̆ üzerine bir anlam karmaşasının olduğu söylenebilir. $\mathrm{Bu}$ nedenle, işgören sessizliği ve örgütsel sessizlik kavramlarının kendine özgü tanımlamalarının yapılmasına ve kullanılmasına ihtiyaç olduğu düşünülmekte ve söz konusu iki kavram üzerine yeni çalışmaların yapılması gerektiği önerilmektedir.

Sağlık hizmetlerinde yapılmış işgören sessizliği ve örgütsel sessizlik ile ilgili toplam 33 çalışma bulunmuştur. Bu çalışmalar makale ve tez olup; tezlerin 6'sına yazarları tarafindan erişim kısıtlanması konulduğu için ulaşılamamıştır. Değerlendirme ise kalan 27 çalışma üzerinde yapılmıştır. Araştırma kapsamına alınan 27 çalışmaya göre; sağlık alanında yapılan çalışmalar ilk olarak 2012 yılında yapılmıştır. Konularına göre yapılan çalışmalara bakıldığında ise, değerlendirmeye alınan 27 çalışmanın 4'ü işgören sessizliği üzerine iken 23'ü ise örgütsel sessizlik üzerine yapılmıştır. İşgören sessizliği üzerine yapılan bu çalışmalardan 2'si yüksek lisans tezi olup 2'si ise araştırma makalesidir. Ancak bu alanda Türkiye'de yapılmış ve Türkçe yayımlanmış herhangi bir makale tespit edilememiştir. Ayrıca literatür incelemesi yapıldığında sıklıkla işgören sessizliği yerine çalışan sessizliği kavramının da kullanıldığ görülmektedir.

Çalışmaların hemşireler üzerinde yoğunlaştığ görülmektedir. Çiriş 2014 yılında bir üniversite hastanesinde çalışan 142 hemşire ile yaptığ çalışmasında; hemşirelerin en çok sessiz kaldığ konuların yönetsel ve örgütsel konular olduğunu tespit etmiştir. Yazın incelendiğinde sağlık çalışanlarında sessizlik üzerine araştırma yapan farklı yazarlar da benzer sonuçlar bulmuşlardır (Yeşilaydın, Bayın \& Yılmaz, 2015; Bayın vd., 2015; Yeşilaydın, Bayın, Esatoğlu \& Yılmaz 2016). Özellikle hastane yönetiminden olumsuz geri bildirim alma ve işten atılma korkusu gibi yönetim kaynaklı birtakım endişeler, çalışanların sessiz kalmasına neden olmaktadır. Dolayısıyla günümüz de örgütlerin potansiyel gelişimi önünde bir engel olarak görülen sessizlik probleminin çözümü, yönetimlerin bu konuya olan ilgi ve tutumlarına göre şekillenmektedir.

Söz konusu çalışmalar da, sessizlik ile ilişkisi sıklıkla incelenen değişkenlerden biri de, örgüt ve çalışan performansıdır. Zira sağlık çalışanlarında yapılan birçok çalışmada (Kılınç 2012; Tayfun \& Çatır 2013; Kılınç \& Ulusoy 2014), örgüt performansı ve örgütsel sessizlik düzeyi arasında anlamlı bir ilişki bulunmuştur. Özellikle örgütsel sessizlik ölçeğinin, örgüt yararına sessizlik boyutu ile çalışan performansı arasında pozitif yönde bir ilişki tespit edilmiştir. Dolayısıyla çalışanların gerek bireysel boyutta gerekse örgüt genelinde sergiledikleri sessizlik halinin örgüt performans1 üzerinde de etkisinin olduğu dikkate alınmalıdır.

Değerlendirmeye alınan makaleler kullanılan anahtar kelimeler bakımından incelendiğinde ise; en çok kullanılan kelime grubunun örgütsel sessizlik olduğu, ardından ise hemşire ve hemşirelik ile ilgili kelimelerin çok sık kullanıldığı dikkat çekmektedir. Performans, örgüt kültürü ve sağlık yönetimi gibi anahtar kelimelerin de bu çalışmalar kapsamında kullanıldığg görülmektedir.

Sonuç olarak sağlık sektörü bakımından "sessizlik" konusunun gündemde kalmaya ve araştırma konusu olmaya devam etmesi gerektiği düşünülmektedir. Konu ve kavramlar çok boyutlu olarak, farklı çalışan gruplarında sessizliğin nedenleri ve sonuçları bağlamında çalışılmalıdır. Sağlık alanına özgü ölçek geliştirme çalışmalarına yer verilmesinin gerekli ve önemli olduğu düşünülmektedir.

Ayrıca bu çalışmanın ileride yapılacak olan sessizlik konulu çalışmalara yol gösterici olacağı düşünülmektedir. 


\section{KAYNAKÇA}

Akarsu, S. F. (2016). Hemşirelerde Çalışan Sessizliği Ve İş Doyumu Arasındaki İlişki (Yüksek Lisans Tezi). Atılım Üniversitesi Sosyal Bilimler Enstitüsü, Ankara.

Aktaş, H. \& Şimşek, E. (2014). Örgütsel sessizlik ile algilanan bireysel performans, örgüt kültürü ve demografik değişkenler arasındaki etkileşim. Akdeniz İ̈FF Dergisi, 28(14), 24-52.

Alparslan, A. M., Ali, C. \& Erdem, R. (2015). Reasons for Employee Silence Behavior: Developing and Validating a Scale for Nurses. Hacettepe Sağllk İdaresi Dergisi, 18(2), 183-204.

Batmunkh, M. (2011). Liderlik tarzları ile örgütsel bağlılık ve örgütsel sessizlik arasındaki ilişki ve bir araştırma. (Yayımlanmamış yüksek lisans tezi). Marmara Üniversitesi, Sosyal Bilimler Enstitüsü, İstanbul.

Bayın, G., Yeşilaydın, G. \& Esatoğlu, A. E. (2015). Hemşirelerde örgütsel sessizlik nedenlerinin belirlenmesi. Işsletme Araştırmaları Dergisi, 7(1), 248266.

Budak, Ö. S. (2015). Kamu Kurumlarında Örgütsel Sessizlik, Etik İklim Ve Yönetim Tarzları Alt Boyutları İlişkilerinin İncelenmesi: Örnek Bir Uygulama (Yayımlanmamış Yüksek Lisans Tezi). Atatürk Üniversitesi Sosyal Bilimler Enstitüsü, Erzurum.

Çakıcı, A. (2007). Örgütlerde Sessizlik: Sessizliğin Teorik Temelleri ve Dinamikleri. Ç. U. Sosyal Bilimler Enstitüsü Dergisi, 16(1), 145-162.

Çakıc1, A. (2010). Örgütlerde İsggören Sessizliği Neden Sessiz Kalmayı Tercih Ediyoruz? Detay Yayıncılık

Çaylak, E. (2014). Hemşirelerde Örgütsel Sessizlik İle Örgütsel Sinizm Ve İsten Ayrılma Niyeti Arasındaki İlişki (Yayımlanmamış Yüksek Lisans Tezi). Atatürk Üniversitesi, Sağlık Bilimleri Enstitüsü, Erzurum

Çaylak, E. \& Altuntas, S. (2017). Organizational Silence Among Nurses: The Impact on Organizational Cynicism and Intention to Leave Work. Journal of Nursing Research, 25(2), 90-98.

Çınar, O., Karcıoğlu, F. \& Alioğulları, Z. D. (2013). The relationship between organizational silence and organizational citizenship behavior: A survey study in the province of Erzurum, Turkey. Procedia-Social and Behavioral Sciences, 99, 314-321.

Çiriş, C. (2014). Üniversite Hastanesinde Görev Yapan Yönetici Hemşirelerin Sessiz Kaldı̆̆ Konular ve Sessizliğini Etkileyen Faktörler (Yayımlanmamış Yüksek Lisans Tezi). Haliç Üniversitesi, Sağlık Bilimleri Enstitüsü, İstanbul.

Demiralay, T. (2014). Hekimlerde Örgütsel Sessizliğin Yapısal Eşitlik Modeli İle İncelenmesi (Doktora Tezi).
Trakya Üniversitesi, Sosyal Bilimler Enstitüsü, Edirne.

Deniz, N., Noyan, A. \& Ertosun, Ö. G. (2013). The relationship between employee silence and organizational commitment in a private healthcare company. Procedia-Social and Behavioral Sciences, 99, 691-700.

Dyne, L. V., Ang, S. \& Botero, I. C. (2003). Conceptualizing Employee Silence and Employee Voice as Multidimensional Constructs. Journal of Management Studies, 40(6), 1359-1392.

Eren, D. (2013). Liderlik Ve Örgütsel Sessizlik: Hasaki Ĕ̈itim Ve Araştırma Hastanesi'nde Çalışma Örneği (Yayımlanmamış Yüksek Lisans Tezi). Beykent Üniversitesi, Sosyal Bilimler Enstitüsü, İstanbul.

Erigüç, G. (2012). Sağlık kurumlarında insan kaynakları yönetimi ve tıbbi personelin önemi, İçinde M. Tatar. Sağlık kurumlarl yönetimi, 1 .

Erigüç, G., Özer, Ö., Sonğur, C. \& Turaç, İ. S. (2014). Bir devlet hastanesinde hemşirelerde örgütsel sessizlik üzerine bir araştırma. Çankırı Karatekin Üniversitesi İktisadi ve İdari Bilimler Fakültesi Dergisi, 4(2), 6184.

Erigüç, G., Özer, Ö., Turaç, İ. S. \& Sonğur, C. (2014). The Causes and Effects of the Organizational Silence: On Which Issues the Nurses Remain Silent? Uluslararast Yönetim İktisat ve İşletme Dergisi, 10(22), 131-153.

Eriguc, G., Ozer, O., Turac, İ. S. \& Songur, C. (2014). Organizational silence among nurses: a study of structural equation modeling. International Journal of Business, Humanities and Technology, 4(1), 150-162.

Hasan, G. \& Özcan, N. (2011). Mobbing ve örgütsel sessizlik arasındaki ilişkiler: Karaman il özel idaresinde görgül bir çalışma. Kahramanmaraş Sütçü Imam Üniversitesi Iktisadi ve İdari Bilimler Fakültesi Dergisi, 1(2), 80-134.

Henriksen, K. \& Dayton, E. (2006). Organizational silence and hidden threats to patient safety. Health Services Research, 41(4p2), 1539-1554.

Kish-Gephart, J. J., Detert, J. R., Treviño, L. K. \& Edmondson, A. C. (2009). Silenced by fear: The nature, sources, and consequences of fear at work. Research in Organizational Behavior.

Kılıçarslan, N. (2016). Yönetici Davranışlarının Işşören Sessizliğine Etkisi: Sağllk Sektöründe Çalışanlar Üzerine Bir Uygulama (Yayımlanmamış Yüksek Lisans Tezi). Nişantaşı Üniversitesi, Sosyal Bilimler Enstitüsü, İstanbul.

Kılınç, E. (2012). Hekim ve hemşirelerde örgütsel vatandaşlık davranışı, örgütsel sessizlik, çalışan performansı ve aralarındaki ilişkinin incelenmesi 
(Yayımlanmamış Yüksek Lisans Tezi). Cumhuriyet Üniversitesi, Sivas.

Kilınç, E. \& Ulusoy, H. (2014). Investigation of organizational citizenship behavior, organizational silence and employee performance at physicians and nurses, and the relationship among them. Business Management Dynamics, 3(11), 25-34.

Knoll, M. \& Van Dick, R. (2013). Do I Hear the Whistle...? A First Attempt to Measure Four Forms of Employee Silence and Their Correlates. Journal of Business Ethics, 113(2), 349-362.

Kostiuk, D. D. (2012). Silence: The Reasons Why People May Not Communicate (Doktora Tezi). University Of Missouri-Columbia.

Morrison, E. W. \& Milliken, F. J. (2000). Organizational Silence: A Barrier to Change and Development in a Pluralistic World. Academy of Management, 25(4), 706-725.

Pinder, C. C. \& Harlos, K. P. (2001). Employee silence: Quiescence and acquiescence as responses to perceived injustice. Research in Personnel and Human Resources Management, 20, 331-369.

Tayfun, A. \& Çatır, O. (2013). Örgütsel sessizlik ve çalışanların performansları arasındaki ilişki üzerine bir araştırma. Işsletme Araştırmaları Dergisi, 5(3), 114134.

Toker, F., Korkmaz, M., Kılıç, B., Yücel, A. \& Gümüş, S. (2014). The Factors Affecting the Organizational Silence of the Nurses And The Other Clinical-care Providers in Turkey, Akademik Bakış Dergisi, 44.

Tülübaş, T. \& Celep, C. (2014). öğretim elemanlarının sessiz kalma nedenleri. Hacettepe Üniversitesi Ĕgitim Fakültesi Dergisi, 280-297.

Uçar, Z. (2015). İşörren Sessizliğinin Kavramsal Yapısina Yönelik Keşifsel Bir Inceleme (Yayımlanmamış Doktora Tezi). İzmir.

Ürek, D., Demir, İ. B. \& Uğurluoğlu, Ö. (2016). Örgütsel Sessizliğin Örgütsel Vatandaşlik Davranişi Üzerindeki Etkisi: Bir Eğitim Ve Araştirma Hastanesi Uygulamasi. İktisadi ve İdari Bilimler Fakültesi Dergisi, 17(3), 122-141.

Yalçın, B. \& Baykal, Ü. (2012). Özel Hastanelerde Görevli Hemşirelerin Sessiz Kaldığ Konular ve Sessiz Kalma Nedenleriyle İlişkili Faktörler. Hemşirelikte Eğitim ve Araştırma Dergisi, 9(2), 42-50.

Yalçınsoy, A. \& Zincirkıran, M. (2016). Örgüt kültürü ve örgüt ikliminin örgütsel sessizlik üzerine etkisinin analizi. Paper presented at the Scientific Cooperation for the Future in the Social Sciences International Conference.
Yeşilaydın, G. \& Bayın, G. (2012). Türkiye'de örgütsel sessizlik ile ilgili yapılan araştırmalara yönelik literatür incelemesi. Anadolu Üniversitesi Sosyal Bilimler Dergisi, 15(4), 103-120.

Yeşilaydın, G., Bayın, G., Esatoğlu, A. E. \& Yılmaz, G. (2016). Örgütsel sessizliğin nedenleri: Kamu hastaneleri çalışanları üzerine bir araştırma. Sosyal ve Ekonomik Arastırmalar Dergisi, 18(31), 14.

Yeşilaydın, G., Bayın, G. \& Yılmaz, G. (2015). Sağlik Personelinin Örgütsel Sessizlik Nedenlerinin Belirlenmesi: Özel Hastane Örneği. Hitit Üniversitesi Sosyal Bilimler Enstitüsü Dergisi, 8(2), 629-646.

Yurdakul, M., Beşen, M. A. \& Erdoğan, S. (2016). The organisational silence of midwives and nurses: reasons and results. Journal of nursing management, 24(5), 686-694. 